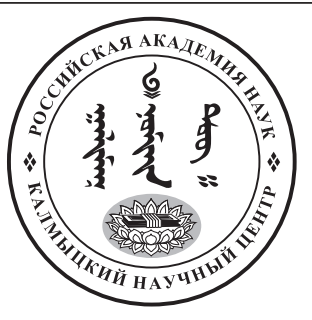

Published in the Russian Federation

Oriental Studies (Previous Name: Bulletin of the Kalmyk Institute

for Humanities of the Russian Academy of Sciences)

Has been issued as a journal since 2008

ISSN: 2619-0990; E-ISSN: 2619-1008

Vol. 13, Is. 1, pp. 173-182, 2020

DOI: $10.22162 / 2619-0990-2020-47-1-173-182$

Journal homepage: https://kigiran.elpub.ru

УДК $930.2+294.321$

\title{
Жизнь и деятельность второго перерожденца Нейджи-тойна: источниковедческий анализ намтара
}

\author{
Цымжит Пурбуевна Ванчикова
}

${ }^{1}$ Институт монголоведения, буддологии и тибетологии СО РАН (д. 6, ул. Сахьяновой, 670047 Улан-Удэ, Российская Федерация)

доктор исторических наук, главный научный сотрудник

iD 0000-0002-1381-6186. E-mail: vanchikova_ts@mail.ru

(C) КалмНЦ РАН, 2020

(C) Ванчикова Ц. П., 2020

Аннотация. Целью статьи является ввод в научный оборот намтара — биографии Агванг-Лобсан-Дамбижалцана, второго перерожденца известного проповедника буддизма Нейджи-тойна Далай Манджушри (1557-1653), сына ойратского князя Мэргэн-Тэбэнэ. Намтар издан в городе Улан-Хад в 2010 г. профессором Алтан-Оргилом. Материалы. В работе даны источниковедческий анализ и характеристика рукописи, написанной в 1756 г. учеником второго перерожденца Дана-Самударой, известным также под именами Уратский Номун-Далай, Уратский Дарма, Чойчжамцо. В результате критики текста биографии выявлены ее структура и содержание, установлено, что структурно она состоит из семи частей, каждая из которых завершается стихотворными кариками, кратко отражающими содержание соответствующей части. Завершается биография пространным колофоном. Результаты. В статье впервые на основе анализа содержания текста приводятся биографические сведения о жизни и деятельности хубилгана Нейджи-тойна, о его роли в истории становления буддизма во Внутренней Монголии, о его взаимоотношениях с маньчжурским двором, о политике цинских правителей в регионе Внутренней Азии. Bblводыl. Данные, изложенные в биографии, позволяют прийти к заключению о том, что в проникновении и развитии буддизма среди разных монгольских этнических групп, наряду со многими объективными социально-политическими факторами, большую роль сыграли и отдельные конкретные буддийские деятели, биография одного из которых рассмотрена в данной статье. Несмотря на недостаточность его личностных характеристик, максимальное приближение биографии рассматриваемого буддийского монаха к жизненноисторическим реалиям подтверждает значительность его деятельности, основной заслугой которого являлось продолжение традиций предшественника по внедрению буддийских практик на монгольском языке, способствовавших его развитию.

Ключевые слова: намтар, второй перерожденец Нейджи-тойна, буддизм, Монголия, роль монгольских лам в геополитике XVIII в.

Благодарность. Статья подготовлена в рамках государственного задания (проект XII.187.1.4. «Культурное наследие народов Трансбайкалья и сопредельных регионов Восточной Азии в системе духовных ценностей России», No AAAA-A17-117021310267-5). 
Для цитирования: Ванчикова Ц. П. Жизнь и деятельность второго перерожденца Нейджи-тойна: источниковедческий анализ намтара // Oriental Studies. 2020. Т. 13. № 1. С. 173-182. DOI: $10.22162 / 2619-0990-2020-47-1-173-182$

UDC 930.2+294.321

\title{
Life and Activities of the $2^{\text {nd }}$ Neiji Toyin: a Historiographic Analysis of His Namtar
}

\author{
Tsymzhit P. Vanchikova ${ }^{1}$ \\ ${ }^{1}$ Institute for Mongolian, Buddhist and Tibetan Studies, Siberian Branch of the RAS (6, Sakhyanova St., \\ Ulan-Ude 670047, Russian Federation) \\ Dr. Sc. (History), Chief Research Associate \\ iD 0000-0002-1381-6186. E-mail: vanchikova_ts@mail.ru
}

(C) KalmSC RAS, 2020

(C) Vanchikova Ts. P., 2020

\begin{abstract}
Goals. The article seeks to introduce into academic discourse a biography (Tib. rnam thar) of Ngag-dbang Blo-bzang Dam pa'i Rgyal-mtshan, the second incarnation of the famous Buddhist preacher Neiji Toyin (1557-1653) who was son of the Oirat Prince Mergen Tebene. Materials. The paper provides a historiographic analysis and description of the manuscript written in 1756 by the $2^{\text {nd }}$ Neiji Toyin's disciple - Dana-Samudara, also known as Urad Nomun-Dalai. The study explores the text of the biography and reveals its structure and contents: the namtar consists of seven parts, each ending with verses that briefly summarize respective chapters. The biography finishes with a lengthy colophon. Results. The article explores the text in detail and for the first time ever provides biographical data dealing with the life and activities of Neiji Toyin's khubilgan (Mong. 'reincarnation'), his role in the history of Inner Mongolian Buddhism, relationship with the Manchu court, and the Qing dynasty's policies in the region. Conclusions. The biography makes it possible to conclude that some Buddhist figures — including the $2^{\text {nd }}$ Neiji Toyin — along with many objective sociopolitical factors did play a large role in the dissemination and development of Buddhism among various Mongolian ethnic groups. Despite the insufficiency of his personal characteristics described, a maximum approximation of this Buddhist monk's biography to the actual historical realities confirms the significance of his efforts.
\end{abstract}

Keywords: namtar, $2^{\text {nd }}$ Neiji Toyin, Buddhism, Mongolia, role of Mongolian priests in $18^{\text {th }}$-century geopolitics

Acknowledgements: The reported study was funded by government assignment (project no. XII.187.1.4. 'Cultural Heritage of Transbaikal Peoples and Adjacent East Asian Regions in the System of Russia’s Spiritual Values’; state reg. no. AAAA-A17-117021310267-5).

For citation: Vanchikova Ts. P. Life and Activities of the $2^{\text {nd }}$ Neiji Toyin: a Historiographic Analysis of His Namtar. Oriental Studies. 2020. Vol. 13. No. 1. Pp. 173-182. (In Russ.). DOI: 10.22162/26190990-2020-47-1-173-182

\section{है}

\section{Введение}

В начальный период истории буддизма в Монголии основными популяризаторами его учения были тибетские монахи, но начиная со второй половины XVI в. в разных регионах, населенных монголами, появились первые монгольские ламы, получившие мо- нашеское образование в монастырях Тибета. Именно появление монгольских монахов в большей степени способствовало успеху и развитию буддизма на всей территории Монголии. В это же время при активной поддержке монгольской знати стали ускоренно строиться буддийские монастыри, значительно 
увеличилась численность монгольского духовенства $^{1}$. Представители монгольской знати - сыновья монгольских ханов и князей объявлялись перерожденцами и становились настоятелями монастырей, проповедниками буддизма. Так, сын халхаского Тушету-хана Занабазар (1635-1723) был объявлен перерожденцем Таранатхи и стал главой буддистов в Халхе. Сын крупнейшего ойратского князя Зая-пандита Намкай-Джамцо (1599-1662) в первой половине XVII в. распространял буддизм в Западной Монголии, а Нейджи-тойн (1557-1653), сын Мэргэн-Тэбэнэ, другого не менее крупного торгутского князя, в последней четверти XVI и первой половине XVII в. был активным проповедником буддизма во Внутренней Монголии. В Бурятии с начала XVIII в. деятельность по распространению буддийского учения начал Дамба-Даржа Заяев (1711-1776), также сын князя, и др. [Бакаева 1994; Норбо 1999; Пурбуева 1984; Ванчикова 2006].

Вокруг этих крупных буддийских деятелей, прославившихся своей проповеднической деятельностью, ученостью или своими благодетельными деяниями, стали формироваться первые монашеские общины.

Следуя тибетской традиции, наиболее крупные монгольские ламы продолжались после ухода в своих перерожденцах, создавая линии преемственности. Наиболее известной из них является линия преемственности 1-го богдо-гэгэна Джебдзун-Дамба-хутухты, сына халхаского Тушету-хана Гомбодоржа, провозглашенного V Далай-ламой в 1650 г. перерожденцем знаменитого проповедника буддизма в Индии и Тибете Таранаты (1573-1635) и духовным главой буддистов Монголии. Его жизнь и деятельность были объектом многих исследований [Позднеев 1993; Бира 1995; Хүрэлбаатар 2001; Bareja-Starzynska 2015; Bawden 1961; и др.].

По мере усиления влияния буддизма в Монголии увеличивается количество хубилганов (перерожденцев) и хутухт (святых), чему, по словам А. М. Позднеева, «способствовали сами халхаские ламы, для которых приобретение в монастырь хубилгана равносильно изысканию средств к удвоению и даже утроению доходности монастыря, а следовательно, и к обеспечению

1 Первый буддийский монастырь Йеке-джу (yeke juu) в Южной Монголии был построен в 1557-1578 г. Алтан-ханом, а в Халха-Монголии Эрдэни-Дзу был построен в 1586 г. Абатай-ханом. его всегдашнего и безбедного существования» [Позднеев 1993: 235].

Со временем хутухты стали занимать привилегированное положение не только среди духовенства, но и в монгольском обществе.

Биографических сочинений на монгольском языке или так называемых намтаров ${ }^{2}$, из которых можно узнать о жизни и деятельности наиболее известных монгольских лам, сохранилось немного, большая часть из них написана на тибетском языке. Все эти биографии ценны не только тем, что описывают жизнь и деятельность того или иного человека в широком историческом контексте, но и тем, что предоставляют ценную информацию о монгольском обществе рассматриваемого периода и являются важными источниками как по истории Монголии в целом, так и по истории буддизма, в частности.

\section{Основная часть}

К числу мало известных и не введенных в научный оборот на русском языке относятся биографии буддийских монахов, продолжавших линию преемственности Нейджи-тойна ${ }^{3}$ Далай Манджушри

${ }^{2}$ Намтар (от тиб. Rnam thar, букв. 'Полностью освободившийся') - этим термином в средневековой литературе обозначают жития буддийских монахов, достигших высших степеней духовного совершенства.

${ }^{3}$ Нейджи - некорректное прочтение слова найджи, которое претерпело в своем историческом употреблении ряд изменений. Согласно Ц. Ж. Жамцарано, найджи - это «дядя, покровитель семьи, заступник, посредник...; шаманка или лама, взявшиеся защищать ребенка от напастей» [Дылыков 1965: 52]. В соответствии с этим определением данное имя может быть переведено как «лама-покровитель, лама-опекун». C распространением буддизма в Монголии функции защиты маленьких детей от болезней и разных напастей стали исполнять ламы. Это слово как составная часть имени было прочитано как «Нейджи» и вошло в литературу в таком варианте. Разъяснение, почему он был так назван, содержится в его биографии: «... почетное имя - Найджи-тойн - [было] дано ему в силу раннего призвания, так как этот богдо-спаситель относился дружелюбно и с жалостью к другим, к подданным простолюдинам... Говорят, что еще отец из-за поведения называл его Найджи-сын. Поэтому среди многих прославился под именем Найджи-тойн» [Пурбуева 1984: 50]. В современном монгольском языке это слово приобрело форму найз 'друг, приятель; подруга, приятельница'. 
(1557-1653), известного своей активной и целенаправленной деятельностью по распространению буддизма среди многих племен Внутренней Монголии и стремлением внедрить в ежедневную монастырскую практику богослужения на монгольском языке. Его почетное имя - Манджушри Далай-богдо, духовное имя - Аригун Шагшабад, обиходное - Нейджи-тойн, его называют и Богдо-гэгэном. Нейджи-тойн известен также и под такими обиходными именами, как Убур-богдо (ӧbür

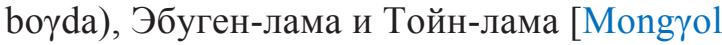
sudulul-un 2007: 124].

Если о жизни и деятельности первого Нейджи-тойна детально повествует биография, написанная его учеником Праджня-Сагарой и изданная ксилографическим путем в 1739 г. [Heissig 1953; Пурбуева 1984], то сведения о продолжателях его линии перерожденцев, игравших значительную роль в истории монгольского буддизма, очень скудны и зачастую разнятся между собой [Mongrol sudulul-un 2007: 124]. Известно, что он стал основоположником линии из девяти перерожденцев, которые проживали в основном в монастыре Бага-джу [Ванчикова 2019: 154-158].

Благодаря публикациям биографии второго перерожденца Нейджи-тойна, изданным в 1989 и 2010 гг., появилась возможность ознакомиться с его жизнью и деятельностью. Впервые текст биографии 2-го перерожденца Нейджи-тойна был опубликован в 6-м выпуске серии монголоязычных документов по истории Хух-Хото наборным способом под заглавием: degedü törülkitü boyda gsnas bju toyin qutuүtu vagisuvara sumati ša sa na duvaza sayin čoүtuyin čadig doluүan erdem tegüsügsen süsüg-ün jula kemegdekü orusiba 'Биография Высокорожденного, великого vagisuvara sumati šasana duvaza богдо Нейджи-тойн-хутухту, именуемая «Лампада веры, преисполненная семью науками»' [Degedü törülkitü 1989: 184-246].

В 2010 г. профессором Алтан-Оргилом была основана серия «Собрание монгольских источников» (Mongyol surbulji bičig-ün kümürge), в первом томе которого изданы биографии Нейджи-тойна (1557-1653) и его перерожденцев [Öbür boyda-yin namtar 2010: 17].

\section{Биография 2-го Нейджи-тойна}

В данном томе, озаглавленном «Öbür boyda-yin namtar», помимо биографии первого Нейджи-тойна, изданы факсимиле рукописной копии биографии второго перерожденца Нейджи-тойна [Öbür boyda-yin namtar 2010: 17, 269-398], наборный текст этой рукописи на классическом монгольском письме с комментариями, а также краткие биографические сведения об остальных семи перерожденцах [Öbür boyda-yin namtar 2010: 17, 399-438].

Издатель перед самой биографией 2-го Нейджи-тойна [Öbür boyda-yin namtar 2010: 268] дает общий заголовок раздела: «Биография 2-го перерожденца хутухту Нейджи-тойна» (Neiji toyin quturtu-yin qoyaduyar düri-yin namtar) и уже далее, на страницах 269-317 книги, приводит машинописный текст биографии, озаглавленный: «Биография Высокорожденного, великого vagisuvara sumati ša sa na duvaza богдо Нейджи-тойн-хутухту, именуемая «Лампада веры, преисполненная семью науками» (degedü törülkitü bo $\gamma d a$ gsnas bju toyin qutu $\gamma t u$ vagisuvara sumati ša sa na duvaza sayin čoytuyin čiday doluyan erdem tegüsügsen süsüg-ün jula kemegdekü orusiba), на страницах 317343 - комментарии, на страницах 344398 - факсимиле рукописи.

Рассматриваемая нами биография была отпечатана в Пекине в 1756 г., оригинал ксилографического экземпляра не обнаружен, она сохранилась только в рукописной копии, хранящейся в библиотеке Академии общественных наук. Рукопись на 55 (r) листах, по 28-30 строк, на листах 1v и 2r по 10 строк, на листе 55r - 18 строк, размеры оригинала не известны, скорее всего, можно предположить, что он был среднего формата. Колофон сочинения приведен на f. 54r-55r (в книге страницы 397-398).

Текст рукописи четкий, крупный, написанный тростниковым пером. На левой стороне всех листов в рамке приводится пагинация на монгольском языке, с указанием лицевой или оборотной стороны, на каждой лицевой стороне листа слева на полях в рамке, наряду с пагинацией в верхней части, дается краткое название сочинения на монгольском языке «с̌аday» ${ }^{4}$ и буква на монгольском галике, обозначающая поряд-

${ }^{4}$ Ошибочное написание вместо с̌аdi (биография, житие, жизнеописание). 
ковый номер данного сочинения или тома в каком-то собрании или коллекции. На правом поле всех листов с обеих сторон в верхней части приводится китайский иероглиф шинг, переводимый как «расцветание» (badaraqu) и обозначающий порядковый номер тома, а также номера страниц с указанием лицевой и оборотной сторон китайскими иероглифами.

На л. $1 \mathrm{v}$ даны изображения божеств (л. 1v с левой стороны Манджушри (Getülgegči Manjusri), с правой - Cарасвати (Янжима, С̆ayan Egesig-tü), на листе $2 \mathrm{r}$ также 3 изображения - с левой стороны изображение 1-го Нейджи-тойна (gsnas bju toyin qutu $\gamma$-tu bo $\gamma$ da blam-a), в середине страницы - изображение Цзонхавы (?), с правой стороны - изображение молодого монаха, скорее всего, 2-го перерожденца Нейджи-тойна (toyin qutu $\gamma$-tu ... $)^{5}$, на последней странице (л. 55r) - 2 нечетких, не подписанных изображения буддийских божеств.

Из данных колофона явствует, что биография второго перерожденца Нейджи-тойна была составлена Дана-Самударой в средний летний месяц 1756 г. основателем линии перерожденцев Гуши цорджи-лам монастыря Мэргэн-джу, расположенного в старом Уланцабском чулгане уратского западно-гунского хошуна [Öbür boyda-yin namtar 2010: 398].

Дана-Самудара (dan-a samudara) ${ }^{6}$ одно из имен уратского Номун-Далая, известного также под именами Уратский Дарма, Чойчжамцо. Биография была составлена по первоначальному замыслу гуна Ламажава и преисполненного верой тайджи Чойджава (egün-i urida-ača sanay-a barilduly-a-tu gung lamajab kiged basa süsüg bilig // f. 55 tegüs tayiji čoyijab qоуayula) и по указанию гелона засаг-ламы храма Ямандаги (dgeslon-ber yamandaga-yin süme-yin jasay-un blam-a), данного преисполненному благих пожеланий Гомбо (süsüg ba sayin sanay-a yabudal tegüsügsen mgonbo-dur), на основе сведений, слышанных или виденных учениками, уратскими старожилами и стариками (Ürida temdeg-ün bičig- // f. 55lüge edüge-yin olan ebüged-ün aman-ača

5 Текст не удалось прочитать из-за нечеткого изображения.

${ }^{6}$ Б. Мунко называет автора Дхарма-Самудаpa [Möngke 1998: 240]. medegsen-nügüd-i dan-a samudr-a kemekü-ber bariyči kemekü yal quluyuna yal naran üker-ün ger ejilegseger-ün jun-u dumda sar-a-yin čayan dötüger bayasqulan-un edür-e bičin üiledügsen egün-iyer) Дарма-Самударой в 4-й радостный день среднего летнего месяца в год огненной мыши, именуемый Bariyči [Öbür boyda-yin namtar 2010: л. 398], который соответствует 1756 г.

\section{Структура сочинения}

Биография состоит из вводной части (лл. 1б-4r (4), основной части - 7 глав (лл. 4r-54r), заключительной части (л. 53r-54r) и колофона 54r (16)-55r (18).

Текст автором биографии разделен на следующие 7 частей.

Первая. О том, как проявился святой перерожденец (Angq-a. Gegen bey-e ile yaruysan anu [dörben degedü] $]^{7}$ $4 r-8 r$.

Вторая. О том, как по повелению императора был приглашен в свой коренной монастырь (Nögüge. Degedü ejen-e ayiladqaju ijayur-un süme-dür jalaysan anu [naima degedü]) - 8r-11r.

Третья. О том, как обучался и прослушал основы коренных знаний (Yutayar. Esi-yin erdem-ün jüil-i suruysan sonosuysan anu [arban nige degedü]) $11 \mathrm{r}-15 \mathrm{v}$

Четвертая. О том, как исполнил повеления верховного владыки императора (Dödüger. Degedü yeke ejen-ü jarli $\gamma$-un jöbšiyel-i bütügegsen anu [arban tabu douradu]) - 15v-32r.

Пятая. O том, как построил объекты почитания, монастыри и дацаны, и основал проведение богослужений (Tabtayar. [Süm-e keyid šitügen-i

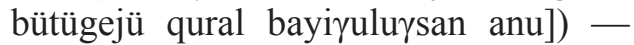
$32 \mathrm{r}-45 \mathrm{r}$

Шестая. О том, как завершил свой жизненный путь и погрузился в нирвану (Jiryuduyar. ... nirvan-a tayalaysan anu [döčin tabu degedü]) - 45r-47v.

Седьмая. О том, как обучившиеся правилам предержания веры, ученики и послушники распространяли учение (Doloduyar. Šasin-i bariqu yosuniyan suraysan jirum-i köbegün šabinar delgeregülügsen anu [döčin dolu-a douradu]) $-47 \mathrm{v}-55 \mathrm{r}$.

${ }^{7}$ В квадратных скобках издатель указал пагинацию частей по факсимиле рукописи. 
При этом каждая часть завершается стихотворным заключением из четырех строк, начинающихся словом ögülerün (сказано), и кратким колофоном, начинающимся словом kemekü (говорят). 1-я часть завершается 2 строфами (с. 274), 2-я - также 2 строфами (с. 276-278), 3-я часть - 3 строфами (c. 281), 4-я часть - 5 строфами (c. 296297), 5-я часть - 3 строфами (с. 307-308), 6-я часть - 3 строфами (с. 310), 7-я часть - 10 строфами (с. 315-316).

\section{Содержание биографии}

Итак, из содержания биографии второго перерожденца Нейджи-тойна явствует, что он родился в первый день среднего осеннего месяца года железного кабана 11-го рабджуна, который соответствует 1671 г., в семье главного (тэригун) хорчинского тайджи хошуна Муминган, входившего во владения брата Чингис-хана - Хасара. Отца его звали Очир, мать - Адис. В 1677 г., когда ему было 7 лет, от имени общего собрания представителей 20 хошунов сеймов Жирим и Джу-уда, двух туметских и трех уратских хошунов, а также хошуна минган было составлено прошение к императору Энх-Амгалану с просьбой подтвердить мальчика перерожденцем Нейджи-тойна.

После получения согласия императора третьего дня первого летнего месяца года овцы-земли (1679 г.) маленького перерожденца торжественно возвели на львиный престол монастыря Бага-джу в Хух-Хото при огромном стечении народа. Празднества длились 3 дня и сопровождались щедрыми подношениями [Öbür boyda-yin namtar 2010: 275]. При этом ему было дано духовное имя Агванг-Лобсан-Дамбижалцан.

Осенью того же года он совершил поездку в Пекин и справился о здравии и благополучии императора, во время аудиенции последний изрек: «Поскольку хутухта родом из Хорчина, восходящего к ханскому роду, то и отношения с государством Цин будут необычными и будут расширяться» [Öbür boyda-yin namtar 2010: 275].

После возвращения в свой монастырь Агванг-Лобсан-Дамбижалцан продолжил обучение у учеников первого Нейджи-тойна Чаган Бирузаны и других ученых лам, изучал труды буддийских философов. Помимо этого, он начал изучение астрологии (чаган джирухай) от Будуун-нояна Билигун-да- лая, правила монгольского языка, правила написания сочинений (букв. «соединения слов» - üge nayirayulqu yosun) [Öbür boydayin namtar 2010: 278]. Принял множество посвящений от известных буддийских просвещенных лам.

В 1687 г. от Галдан-ширету Агван-Лоройжамцо он принял обеты гелона и абишиг Ямандаги с 13 бурханами. В 21-летнем возрасте в своем монастыре принял халхасского Зая-пандиту и прослушал от него «Методы созерцания Нигуца Хуриянгуй» и другие книги (учения). В 1703 г. получил учения от Чжанжа-[хутухты] Агванг-Лобсан-Чойдана (1642-1714) и Зая-пандиты Лубсанпринлея (1642-1715).

Впоследствии он несколько раз был с визитами у маньчжурского императора (в 1690, 1691, 1693, 1695, 1696 гг.), и каждая его встреча сопровождалась щедрыми вознаграждениями и поощрениями. Так, в 1690 г. император наградил его 15-ю дудие ${ }^{8}$ и назначил его засаг-ламой ${ }^{9}$ (jasa ${ }^{2}$ blam-a

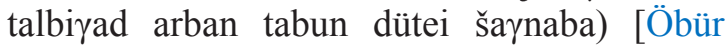
boyda-yin namtar 2010: 281], в 1691 г. Агванг-Лобсан-Дамбижалцан вместе с императором Энх-Амгаланом принял участие в сейме, созванном в Долонноре, на котором 7 халхаских хошунов приняли подданство маньчжуров, за что он был поощрен наравне с Джебцзун-Дамба-хутухтой.

В тот же год 2-й Нейджи-тойн посетил императора, который, обрадовавшись, организовал ему торжественную и пышную встречу, наградил его щедрыми подарками и выдал разрешение 108 человекам стать ламами [Öbür boyda-yin namtar 2010: 284].

В 1693 г. император выделил ему храм Ямандаги в Шира-хото, одном из восьми пекинских императорских монастырей, сказав: «Вы можете останавливаться в нем каждый год во время приезда в Пекин, поскольку вы будете совершать богослужения на

${ }^{8}$ Düdei - по словарю O. М. Ковалевского dutiy-a - «вид на вступление в монашество» [Ковалевский 1849: 1838]. Dùdié (кит.) - официальное свидетельство, разрешающее пострижение и причисление к монастырскому монашескому штату, дававшее освобождение от налогов и повинностей [Öbür boyda-yin namtar 2010: 339].

9 Засаг-лама - главный лама монастырской администрации (tamay-a-yin yajar-tu terigün blam-a) [Mongyol sudulul-un 2007: 667]. 
монгольском языке, то можете разместить в нем 20 лам» [Degedü törülkitü 1989: 202]. При этом назначил пособие на содержание настоятеля храма и 20 лам и оплату всех монастырских расходов из императорской казны. Это был единственный в столице храм, в котором богослужения проводились на монгольском языке [Öbür boyda-yin namtar 2010: 11-12, 284].

В 1694 г. по просьбе хорчинских князей и знатных людей вместе со многими своими учениками отправился из Хух-Хото в Бааринский, восточный и западный Джарутский и другие хошуны Внутренней Монголии, где совершил множество обрядов очищения и устранения помех и препятствий. На протяжении недолгой жизни неоднократно посещал разные монастыри и земли, где давал многодневные учения и посвящения всем желающим [Öbür boyda-yin namtar 2010: 285].

Более того, 2-й перерожденец Нейджи-тойна выполнял доверительные политические поручения императора и служил посредником между последним и тибетскими буддийскими иерархами. Так, в 1695 . Энх-Амгалан отправил в Тибет послов во главе со 2-м перерожденцем Нейджи-тойна на встречу с V панчен-ламой с приглашением и попутно разузнать о V Далай-ламе, жив он или нет (jarim-ud dalai blam-a edüge bui ügei gekü buyin tula daširam-iyar medejü ire kemen jarliy tušiyayad, f. 289). Нейджи-тойн, посетив по пути известные монастыри Гонлун, Гумбум, Сэра, Галдан, Брайбунг, прибыл в Лхасу, затем встретившись с 5-м панчен-ламой в его монастыре Рашилхунбо (Дашилхунбо), передал ему приглашение от императора. Но по причине эпидемии оспы приглашение не было принято [Öbür boydayin namtar2010: 291]. За время пребывания в Тибете он получил разные учения и посвящения от известных тибетских лам-перерожденцев - от панчен-ламы, от хутухту Галдан-ширету и др.

Вернувшись в последний весенний месяц следующего года в Пекин, сообщил императору о внутренней обстановке в Тибете, за что был высоко отмечен императором и щедро вознагражден (eldeb jüil-ün ed tor $\gamma$-abar yurban jayu yar-un lang alta yurban tümen yar-un lang mönggün ming $\gamma$-a siqam tor $\gamma$-a tümen qada $\gamma$ kkib-i jaručayulbai) [Öbür boydayin namtar 2010: 292].
К услугам II Нейджи-тойна Энх-Амгалан прибегал и во время нашествия Галдан Бошогту-хана весной 1696 г. Так, весной 1696 г. Энх-Амгалан во время нашествия Галдан Бошогту-хана взял II Нейджи-тойна с собой в поход в качестве ламы-покровителя трех больших армий, для которого поставил отдельную юрту в своей ставке. И, по словам автора биографии, «не расставаясь с императором ни на день, заслужил его милость и покровительство» [Öbür boyda-yin namtar 2010: 292].

После завершения военных кампаний император на обратном пути посетил Хух-Хото, монастырь Бага-джу, в котором специально провел 3 дня, а для усиления значимости и влияния монастыря оставил в нем свои военные доспехи, меч, копье [Öbür boyda-yin namtar 2010: 292].

В 1698 г. император попросил II Нейджи-тойна и Джебцзун-Дамба-хутухту провести обряд почитания предков в Мукдене. В том же году Энх-Амгалан назначил II Нейджи-тойна главным ламой, управляющим всеми ламами и хувараками (jasay-un terigün blam-a-bar tomilaju) всех монастырей Йеке-джу.

За период нахождения на этом посту им были отремонтированы или отреставрированы не только основные храмы Хух-Хото - Йеке-джу и Бага-джу, но и множество храмов в других хошунах.

В 1700 г. II Нейджи-тойн по наказу хагана водворил в монастыре Бага-джу посвященную победе над Галданом каменную стелу с текстом, вырезанным на 4 языках (маньчжурском, китайском, монгольском и тибетском).

В 1701 г. посетил Пекин по случаю дня рождения императора, после чего вместе с ним посетил монастыри Утайшаня с целью поклонения и совершения молебствий.

Летом 1703 г. II Нейджи-тойн вернулся в свой монастырь, где в 1704 г. скоропостижно скончался в возрасте 33 лет.

Так, на примере биографии 2-го перерожденца Нейджи-тойна подтверждаются тенденции выявления перерожденцев в начальный период распространения буддизма из среды монгольской знати и их тесной взаимосвязи с правящим маньчжурским двором. Благодаря появлению монгольских лам, доступно разъяснявших основные положения буддийского вероучения на мон- 
гольском языке и массово практиковавших обряды посвящения, буддизм смог быстро проникнуть во все слои монгольского общества. К основным заслугам 2-го Нейджи-тойна относится то, что он способствовал распространению монгольского языка, монгольской письменной культуры, хотя, конечно же, одной из главных причин для этого было его стремление приблизить буддийское учение к народу [Ванчикова 2011: 156], сделать его понятным и доступным для восприятия верующими монголами. Он продолжил традицию чтения служб на монгольском языке, начатую 1-м Нейджи-тойном, потому уделял особое внимание проведению богослужений на монгольском языке, сам возглавлял хуральные службы чтения монгольского Ганджура.

Успеху буддийской церкви способствовали также богатые и обильные подношения, которые фактически создавали материальную базу становящейся буддийской церкви среди монгольских племен.

Намтар подтверждает то, что большинство монгольских хубилганов и хутухт обучались в тибетских, в основном в амдоских, дацанах, становились учениками крупных тибетских ученых лам, получали посвящения и благословения у далай-лам и панчен-лам и напутствие на распространение буддийского учения среди монголов.

\section{Заключение}

Если биография первого Нейджи-тойна написана в индо-тибетской агиографиче-

\section{Литература}

Бакаева 1994 - Бакаева Э. П. Буддизм в Калмыкии. Историко-этнографические очерки. Элиста: Калм. кн. изд-во, 1994. 128 с.

Ванчикова 2006 - Ванчикова Ц. П. История бурятского буддизма: письменные источники. Улан-Удэ: Изд-во БНЦ СО РАН, 2006. 154 с.

Ванчикова 2011 - Ванчикова Ц. П. Биографии последователей Нейджи-тойна // Вестник Бурятского научного центра СО РАН. 2011. № 1. С. $81-88$.

Ванчикова 2019 - Ванчикова Ц. П. Буддизм в Монголии: история, духовенство, монастыри. Иркутск: Оттиск, 2019. 292 с.

Дылыков 1965 - Халха Джирум: памятник монгольского феодального права XVIII в. / сводный текст и перевод Ц. Ж. Жамцарано; подготовка текста к изданию, редакция пе- ской традиции, то биография второго перерожденца Нейджи-тойна схожа с монгольскими летописями, излагающими события по годам. Она представляет интерес для исторической реконструкции взаимоотношений между буддийской церковью и властью, взаимоотношений между Тибетом, Китаем и монгольским миром, истории возникновения и распространения института перерожденцев в Монголии, взаимоотношений между людьми, основанных на религиозном авторитете и почитании духовных учителей. Эта биография частично восполняет пробел в знаниях ранней истории буддизма, истории его распространения и бытования в определенных регионах Монголии, вызванный скудостью письменных источников. Данные биографии позволяют прийти к заключению о том, что в проникновении и развитии буддизма среди разных монгольских этнических групп, наряду с объективными социально-политическими факторами, большую роль сыграли и отдельные конкретные буддийские деятели, биография одного из которых рассмотрена в данной статье. Именно благодаря их деятельности буддийское учение и церковь начали играть важную роль и стали неотьемлемой составной частью духовной жизни монгольских народов. Несмотря на скудость личностных характеристик второго перерожденца Нейджи-тойна, максимальное приближение его биографии к жизненно-историческим реалиям подтверждает значительность его деятельности.

ревода, введение и примечания С. Д. Дылыкова. М.: Наука, 1965. 339 с.

Ковалевский 1844-1849 - Ковалевский О. М. Монгольско-русско-французский словарь. В 3 т. Т. 3. Казань: Тип. Казанского университета, 1849. С. 1546-2690.

Норбо 1999 - Норбо Ш. Зая-пандита (Материалы к биографии). Перевод со старописьменного монгольского языка Д. Н. Музраевой, К. В. Орловой, В. П. Санчирова. Элиста: Калм. кн. изд-во, 1999. 335 с.

Позднеев 1993 - Позднеев А. М. Очерки быта буддийских монастырей и буддийского духовенства в Монголии в связи с отношениями сего последнего к народу. 1887. Серия «Наше наследие». Изд. репринтное. Элиста: Калм. кн. изд-во, 1993. 512 с. 
Пурбуева 1984 - Пурбуева Ц. П. «Биография Нейджи-тойна» - источник по истории буддизма в Монголии. Новосибирск: Наука, Сиб. отд-ние, 1984. 113 с.

Бира 1995 - Зая бандид Лувсанпринлэй. Живзундамба Лувсанчойжижалцанбогийн ердийн товч намтар. Түвэд хэлнээс орчуулж эрдэм шинжилгээний тайлбар бичсэн академич Ш. Бира (Зая-пандита Лувсанпринлэй. Краткий намтар Джебдзундамбы Лувсанчойжижалцанбо. Перевод с тибетского с научными комментариями Ш. Бира). Улаанбаатар: ЭРДЭМ, 1995. 48 с.

Хүрэлбаатар 2001 - Хүрэлбаатар Л. I богд Жавзандамбалувсандамбижанцан (I богдо Жавзандамбалувсандамбижанцан). Улаанбаатар: Хаадын сан, 2001. 27 с.

Degedü törülkitü 1989 — Degedü törülkitü boyda gsnas bju toyin quturtu vagisuvara sumati ša sa na dhuvaza sayin čo erdem tegüsügsen süsüg-ün jula kemegdekü orusiba (= Биография Высокорожденного, великого vagisuvara sumati ša sa na duvaza богда Нейджи-тойн-хутухту, именуемая «Лампада веры, преисполненная семью науками) // Kökeqota-yin teüken mongyol surbulji bicig. Хух-хото: Изд-во комитета по культуре Внутренней Монголии, 1989. 499 с.

Mongyol sudulul-un 2007 - Mongyol sudulul-un nebterkei toli. Šasin surtaqun (Энциклопедический словарь по монголоведению. Религиоведение). (Encyclopeadia of Mongolian

\section{References}

[Biography of the Prominent Noble Bogdo Neiji Toyin Khutukhtu Titled 'The Oil Lamp of Faith Abundant in (Fed by) the Seven Sciences'. Ser. 'Kökeqota-yin teüken mongyol surbulji bicig'. Hohhot: Inner Mongolia Committee for Culture, 1989. 499 p. (In Mong.)

[Encyclopedia of Mongolian Studies: Religion]. Ulankhad: Inner Mongolia People's Publ. House, 2007. 833 p. (In Mong.)

[Khalkha Dzhirum: a Monument of $18^{\text {th }}$-Century Mongolian Feudal Law]. Ts. Zh. Zhamtsarano (comp., transl.); S. D. Dylykov (ed., foreword, etc.). Moscow: Nauka, 1965. 339 p. (In Russ.)

[Namtar (biography) of Öbür boyda]. Ser. 'Collected Mongolian-Language Sources'. Vol. 1. Ulankhad: Inner Mongolia Committee for Culture, 2010. 521 p. (In Mong.)

Bakaeva E. P. [Buddhism in Kalmykia: Historical and Ethnographic Essays]. Elista: Kalmyk Book Publ., 1994. 128 p. (In Russ.)

Bawden Ch. The Jebtsundamba Khutukhtus of Urga. Text, Translation and Notes. Ser. studies on religions). Ulayanqada: öbür mongyol-un arad-un keblel-ün qoriy-a. šasin surtaqun-u boti (Народное изд-во Внутренней Монголии), 2007. 833 с.

Möngke 1998 - Möngke B. Nomundalai kiged tegun-ü "Süsüg-ün jula" // Mongyol burqan-u šasin-u uran jokiyal-un sudulul (Номундалай и его «Светильник веры»// Исследования монгольских буддийских литературных произведений). Huhhot: Изд-во комитета по культуре Внутренней Монголии, 1998. C. 240-269.

Öbür boyda-yin namtar 2010 — Öbür boyda-yin namtar // Mongyol surbulji bičig-ün kümürge (НамтарУбур-богдо // Собрание монгольских источников). В. 1. Ulayaanqada: Изд-во комитета по культуре Внутренней Монголии. 2010. 521 с.

Bareja-Starzynska 2015 - The Biography of the First Khalkha Jebtsundampa Zanabazar by Zaya Pandita Luvsanprinlei. Studies, Annotated Translation, Transliteration and Facsimile by Agata Bareja-Starzynska. Warsaw: ELIPSA, 2015. 414 p.

Bawden 1961 - Bawden Ch. The Jebtsundamba khutukhtus of Urga. Text, translation and notes // Asiatische Forschungen. Bd. 9. Wiesbaden: Otto Harrassowitz, 1961. 142 p.

Heissig 1953 - Heissig $W$. Mongolian source to the Lamaist suppression of shamanism in the XVII- ${ }^{\text {th }}$ century // Anthropos. 1953. Vol. 48, fasc. 1-2. P. 1-29; fasc. 3-4. Pp. 492-536.

Asiatische Forschungen. Vol. 9. Wiesbaden: Otto Harrassowitz, 1961. 142 p. (In Eng. and Mong.)

Heissig W. Mongolian source to the Lamaist suppression of shamanism in the XVII-th century. Anthropos. 1953. Vol. 48. Fasc. 1-2, pp. 1-29; fasc. 3-4, pp. 492-536. (In Eng. and Mong.)

Khürelbaatar L. [The $1^{\text {st }}$ Jebtsundamba Khutukhtu Blo-bzang Bstan-pa'i Rgyal-mtshan]. Ulaanbaatar: Khaadyn San, 2001. 27 p. (In Mong.)

Kovalevsky O. M. [Mongolian-Russian-French Dictionary]. In 3 vols. Vol. 3. Kazan: Imperial Kazan University, 1849. Pp. 1546-2690. (In Mong., Russ. and Fr.)

Möngke B. Nomundalai and his 'Oil Lamp of Faith'. In: [Studies in Mongolian Buddhist Literature]. Hohhot: Inner Mongolia Committee for Culture, 1998. Pp. 240-269. (In Mong.)

Norbo Sh. [Zaya Pandita: Biographical Materials]. Muzraeva D. N. et al. (transl.). Elista: Kalmyk Book Publ., 1999. 335 p. (In Russ.) 
Pozdneev A. M. [Essays on Everyday Life of Mongolian Buddhist Monasteries and Clergy, in Relation of the Latter's Attitudes towards the People: 1887]. Ser. 'Our Heritage'. Reprint. Elista: Kalmyk Book Publ., 1993. 512 p. (In Russ.)

Purbueva Ts. P. [Buddhism in Mongolia: Biography of Neiji Toyin as a Historical Source]. Novosibirsk: Nauka, 1984. 113 p. (In Russ.)

The Biography of the First Khalkha Jebtsundampa Zanabazar by Zaya Pandita Luvsanprinlei. A. Bareja-Starzynska (studies, annot. transl., translit. and facsimile). Warsaw: ELIPSA, 2015. 414 p. (In Eng. and Mong.)

Vanchikova Ts. P. [Buddhism in Mongolia: History, Clergy, Monasteries]. Irkutsk: Ottisk, 2019.
292 p. (In Russ.)

Vanchikova Ts. P. [History of Buryat Buddhism: Written Sources]. Ulan-Ude: Buryat Scientific Center (Sib. Branch) of the RAS, 2006. 154 p. (In Russ.)

Vanchikova Ts. P. Biographies of Neiji Toyin's disciples. The Bulletin of the Buryat Scientific Center of the Siberian Branch of the Russian Academy of Sciences. 2011. No. 1. Pp. 81-88. (In Russ.)

Zaya Pandita Blo-bzang 'Phrin-las [A Brief Biography of Jebtsundamba Khutukhtu Blobzang Chos-rje Rgyal-mtshan]. Sh. Bira (transl., comment.). Ulaanbaatar: ERDEM, 1995. 48 p. (In Mong.) 